\title{
Prediction of the partition coefficient between air and body compartments from the chemical structure
}

\author{
Stefanie Stöckl ${ }^{*}$, R Kühne, R-U Ebert, G Schüürmann \\ From 5th German Conference on Cheminformatics: 23. CIC-Workshop \\ Goslar, Germany. 8-10 November 2009
}

For PBPK modeling, partition coefficients between tissues and environmental compartments are required. A simple approach starts with the system blood/air, fat/air, and fat/blood. Employing thermodynamic relationships, one of the three coefficients can be calculated from the other two values. With respect to available human and mammal data, modeling efforts focus on the blood/air and fat/air partition coefficient.

Respective data sets from literature have been collected and evaluated. The chemical domain of the sets is presented in terms of chemical structure, complexity, and polarity. Data gaps have been identified.

The blood/air and fat/air partition coefficient data sets have been applied to a validation of literature models, with particular remark on the performance for specific compound classes. A new model for the blood/air partition coefficient and a preliminary new model for the fat/ air partition coefficient are presented.

The study was supported by the EU projects $2 \mathrm{FUN}$ (contract No. 036976) and OSIRIS (IP, contract No. 037017).

Published: 4 May 2010

doi:10.1186/1758-2946-2-S1-P9

Cite this article as: Stöckl et al.: Prediction of the partition coefficient between air and body compartments from the chemical structure. Journal of Cheminformatics 2010 2(Suppl 1):P9.
Publish with ChemistryCentral and every scientist can read your work free of charge

"Open access provides opportunities to our colleagues in other parts of the globe, by allowing anyone to view the content free of charge." W. Jeffery Hurst, The Hershey Company.

- available free of charge to the entire scientific community

- peer reviewed and published immediately upon acceptance

- cited in PubMed and archived on PubMed Central

- yours - you keep the copyright

Submit your manuscript here:

http://www.chemistrycentral.com/manuscript/

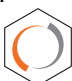
Chemistry Central 